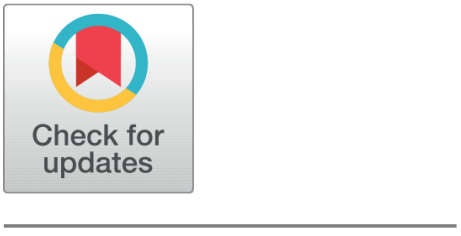

OPEN ACCESS

Received: 21.06 .2021

Accepted: 03.11.2021

Published: 25.11 .2021

Citation: Aguilar MAA, Braganza JC, Guiwanas GD, Magpayo EC, Patacsil FF (2021) Design and Implementation of i-Inhs: A Learning Management System for Lananpin National High School. Indian Journal of Science and Technology 14(39): 2982-2997. https://doi.org/ 10.17485/IJST/V14i39.1142

* Corresponding author.

frederick_patacsil@yahoo.co.uk

Funding: None

Competing Interests: None

Copyright: @ 2021 Aguilar et al. This is an open access article distributed under the terms of the Creative Commons Attribution License, which permits unrestricted use, distribution, and reproduction in any medium, provided the original author and source are credited.

Published By Indian Society for Education and Environment (iSee)

ISSN

Print: 0974-6846

Electronic: 0974-5645

\section{Design and Implementation of i-Inhs: A Learning Management System for Lananpin National High School}

\author{
Mary Ann A Aguilar ${ }^{1}$, Jeroll C Braganza르, Gemalyn D Guiwanas ${ }^{3}$, \\ Eugene C Magpayo ${ }^{3}$, Frederick F Patacsil ${ }^{4 *}$ \\ 1 Lananpin National High School, Urdaneta City, 2428, Philippines \\ 2 San Nicolas National High School, Patricio St., San Nicolas, Pangasinan, 244, Philippines \\ 3 Cuyapo National High School, Bulala, Cuyapo, Nueva Ecija, 3117, Philippines \\ 4 Pangasinan State University-Urdaneta City Campus, 2428, Urdaneta City, Philippines
}

\section{Abstract}

Background/ Objectives: The use of technology such as Learning Management System (LMS) is helpful during the pandemic to enforce distance learning in public schools in the Philippines. The Department of Education (DepEd) introduced various formats and platforms to teachers to cope with the situation mentioned and to attain continuous learning amidst any circumstances. However, in some cases like in Lananpin National High School (LNHS) which used to implement traditional method, modernization without consideration of technological acceptability issues has reduced the influence of e-learning and the desired academic achievement. In this regard, the researchers conducted this study to find out the level of acceptability and usability of i-Inhs; a learning management system for Lananpin National High School using an e-learning platform, Modular Object-Oriented Dynamic Learning Environment (Moodle), to address the existing learning gaps. The objective of this research is to examine the implementation of $\mathrm{i}$-Inhs to help the teachers and students facilitate learning and easily monitor students' progress. Methods: This study used a descriptive and developmental research design. A questionnaire survey was used to assess teacher and student acceptance in implementation, content validity, and technological acceptability. Respondents were purposively chosen; 11 senior high school teachers and 40 senior high students. Data was obtained using Google Forms and was analyzed thereafter. Findings: The result showed that the implementation of $\mathrm{i}$-Inhs in terms of functions and capability requirements, user interface and design, content validity, technical quality, and usability were acceptable to teachers and students. Therefore, the use of this technology could address the gaps of distance learning and the skepticism of teachers and students to adapt shift in learning methodology.

Keywords: ilnhs; Learning Management System; Moodle; elearning; Descriptive and Developmental research design 


\section{Introduction}

Technology and ICT improved our ability to interact, collaborate, and quickly access thousands of pieces of knowledge. As computers and smartphones became more widely available, teachers could broaden the reach of education because face-toface contact was no longer the only option ${ }^{(1)}$. This educational transition allows educators to incorporate modern learning environments such as e-learning alongside the conventional classroom setting. However, due to the Covid 19 outbreaks, classroom settings changed dramatically ${ }^{(2)}$. According to UNESCO, the nationwide school lock down has affected more than 177 million students in 165 countries.

Since face-to-face classes are not allowed in the Philippines due to restrictions imposed by the COVID-19 pandemic, there is a greater need for a medium that enables teachers to conduct online lessons for students with internet access ${ }^{(3)}$. As a result, schools, colleges, and universities were forced to use online learning to replace on-site delivery ${ }^{(4)}$.

The Department of Education began to train its teachers to adapt to what is referred to as the "new normal," introducing ICT resources to promote the new learning process and scheme, such as video lectures, television broadcasts, E-Self Learning Modules, and the use of Learning Management Systems (LMS) ${ }^{(5)}$.

To expand and reinforce teachers' knowledge in developing learning aides as part of the DepEd learning continuity plan, the Regional Office of Region 1 conducted further training and capacity building on the use of advanced technology. Webinars on open educational resources and developing self-learning modules (SLM) were also conducted. These would help teachers to become equipped in delivering education to learners amid any circumstance. However, based on the survey conducted by DepEd this school year, parents and students preferred Modular Learning as a learning delivery method for their children. Materials for modular learning can be printed or digitally, Manila Bulletin reported. ${ }^{(6)}$.

Lananpin National High School is one of Urdaneta City's largest schools, with 1078 students enrolled in Junior and Senior High schools in the school year 2020-2021. Teachers used printed SLM as a primary mode of teaching and learning. In the existing process, teachers schedule a distribution and retrieval day where parents could come to school to get or return the students' SLMs. Some gave supplemented videos; others send learning materials from different resources, or some ways teachers find it comfortable and easy to implement platforms to adapt to the evolving world of distance learning. When we look at distance education students, we see a self-directed learning path and full of responsibility. However, SLMs were insufficient to inspire and empower students to learn on their own. According to a retrieval and distribution monitoring report from Grade 12 teachers in senior high school, 90 percent of SLMs were distributed for the first semester of the school year 2020-2021. However, only 65 percent of completed SLMs were retrieved. Feedback from teachers for re-enforcement also takes time because teachers must review all of the retrieved modules first to track their progress. Teachers looked into using sort of ways to fill-in the gaps of low retrieval rate such as phone calls, text and instant messaging to follow-up and monitor their students. In this case, the researchers came up with implementing "i-lnhs: A Learning Management System" to help teachers and students achieved their academic goals and examine its acceptability since no LMS was implemented yet in the school. It will be implemented as the alternative way for students who have an internet connection to access their SLMs anytime and anywhere.

The main objective of this study is to implement and design i-lnhs to help the teachers and students facilitate on-learning and easily monitor students' performance progress. Specifically, to identify important capabilities and features of i-lnhs needed to facilitate e-learning and to determine its acceptability and validity in terms of functions and capability requirements, user interface and design, content, technical quality, and usability.

\section{Review of Literature}

In the recent years, there has been a dramatic increase with the use of computers and the internet as educational tools. It is one indication of the internet's rising presence in our lives. Before, sitting in a classroom, listening to the lecture, and taking notes on paper were common in education. Then, computers evolved. Approaches moved towards more technical methods, such as using PowerPoint presentations in the classroom or pdf files to exchange notes with students and using e-learning tools today ${ }^{(7)}$.

\subsection{Effectiveness of E-Learning}

E-learning is a form of learning that occurs outside of a traditional classroom setting. It requires the use of electronic technology to access educational material ${ }^{(8)}$. Ayo, Ajayi, Okorie conducted a study to demonstrate the advantages of e-learning in fostering academic achievement through improved learning processes, academic research motivation, self-development outcomes, and academic performance results. The study's findings indicated that e-learning-facilitated studies significantly improved academic performance, learning processes, and self-development ${ }^{(9)}$. Also, in the research, they found that the ability of students to 
study at their leisure and at their own pace expanded learning outside the classroom. Greater involvement with the assigned coursework means, students have more time to think and reflect about what has been discussed and learned leading to a greater understanding of deeper approaches to learning and, as a result, better outcomes ${ }^{(10)}$.

\subsection{Learning Management System improving Academic Performance}

A Learning Management System (LMS) is a software tool that allows end-users to access learning information and other tools. In such an environment, the use of Learning Management Systems in education provides an excellent alternative to schools and colleges, allowing teachers to provide personalized content, utilize different pedagogical styles, and involve their students even more than ever ${ }^{(11)}$.

With the use of LMS (Moodle), students performed better. Oguguo, Nannim and Aga recommend that LMS Packages such as Moodle be learned and used by Educational Measurement and Evaluation lecturers. ${ }^{(10)}$

\subsection{Features and Capabilities of Moodle as an E-leaning platform}

The use of LMS to manage teaching and learning activity has a significant impact on the delivery of education and speeding up the process and access and reducing traditional administration processes. E-learning platforms such as LMS are supported with various features that support the implementation of online lectures and learning ${ }^{(12)}$.

In addition, LMS is described by Reischl and Toroa as a piece of software that allows you to create, distribute, and manage instructional content delivery through various educational activities, the monitoring and reporting of student information, and the ability to promote and distribute communication ${ }^{(13)}$. Hurix also stated that, while educational institutes can impart knowledge in various ways, one of the most successful methods of providing online training is through a Learning Management System (LMS) ${ }^{(11)}$.

MoodleTM is an acronym that stands for Modular Object-Oriented Dynamic Learning Environment. Martin Dougiamas founded and created MoodleTM in $2002^{(14)}$.

The study of Ocampo, Mandi, and Biset showed that Moodle has made a significant contribution to the educational sector by providing an improving platform for Virtual Learning Management Systems (VLMS), which has considered widely used for most educational institutions worldwide. One reason is that it meets the needs of a VLMS by not only providing a visual platform for learning activities but also by delivering digital resources to keep grade books, handle interaction channels as well as the evaluation process using various educational tools, build competency-based learning plans and monitor learning through the educational capabilities supplied ${ }^{(15)}$.

Buttan, Chaurasia, Chourishi1, and Soni ${ }^{(16)}$ investigated the various E-learning supports provided by Moodle. Moodle is an excellent tool for tutors because it allows them to quickly build and save instructional materials and provide a shared online forum for teachers and students to learn together.

As a result, incorporating e-learning using Moodle allows for greater educational efficacy. E-learning encourages more cooperation among teachers, and learners. E-learning will improve accessibility, usability, and collaborative learning, as well as student and teacher motivation.

Furthermore, Alhothli and Nada discovered that 100 percent of students recorded that using Moodle as an e-learning tool helped them become more organized in completing course requirements, even when there was no supervision. The viewpoint of the students, using Moodle as an e-learning platform can be a huge benefit to their learning needs ${ }^{(17)}$.

\subsection{Hannafin-Peck Model in e-Learning Development}

The activities that will lead to the creation of eLearning projects are defined using an instructional design model. It enables researchers to express the strategy's aim and reasoning. A framework provides a design platform and development environment overview of all the essential components covered in the course ${ }^{(18)}$.

The Hannafin-Peck Model is built on three phases: assessment, design, and implementation. It is the best technique for a more complicated subject since it independently addresses each stage of the eLearning creation process.

The 3 Phases of The Hannafin-Peck Model

1. Assessment - The first step of the process entails doing a comprehensive requirement review. This stage covers the online learners' interests, such as their aspirations and achievement differences and the organization's needs. Establish goals and begin to consider which eLearning activities and opportunities can best help to accomplish them. To define the learners' interests, use eLearning tests, polls, and other engagement methods. 
2. Design - The design of the eLearning experience is the second stage of the Hannafin-Peck Model. The time to plan every part of the eLearning curriculum and develop a storyboard or blueprint highlighting the online drills, interactive elements, and eLearning tests researchers will use.

Essentially, the design stage is where researchers start putting all the pieces together and figure out how to close output holes and meet the needs and desires of the learners. Gather all the tools and online materials for the Hannafin-Peck Model in eLearning's design process so that researchers can develop a plan of action.

3. Development \& Implementation - The third and final step is designing and launching the eLearning program. It usually involves holding the program up to date and updating it regularly to meet the learners' ever-changing needs. Proofread and update the eLearning materials to guarantee that they are in order, verify all, and teach the learners by including specific eLearning instructions.

When using the Hannafin-Peck Model in eLearning, evaluation is part of the revision process during each phase. As a result, researchers can carefully review and evaluate any aspect of the eLearning software to catch errors ${ }^{(19)}$.

\subsection{Conceptual Framework}

This study aims to design and implement “i-lnhs: A Learning Management System for Lananpin National High School”. This study was derived from various concepts related to online education such as e-learning, learning management systems, selfpaced learning, collaborative learning, and alternative approach.

This study is also anchored to the different stages of Hannafin Peck Model. This will serve as a guide in developing and implementing the LMS.

In addition, Acceptability has recognized as a critical factor in the design, development, and deployment. Acceptability refers to determining how well a new intervention will be welcomed by the target population and how well it will meet the demographic and organizational needs of the target group. In this study, the acceptance of teachers and students are essential for the LMS to be implemented and to adapt to e-learning.

\subsection{Project Paradigm}

The study's conceptual framework in implementing-i-lnhs is depicted in the project paradigm. The input, method, and output are all part of the project paradigm.

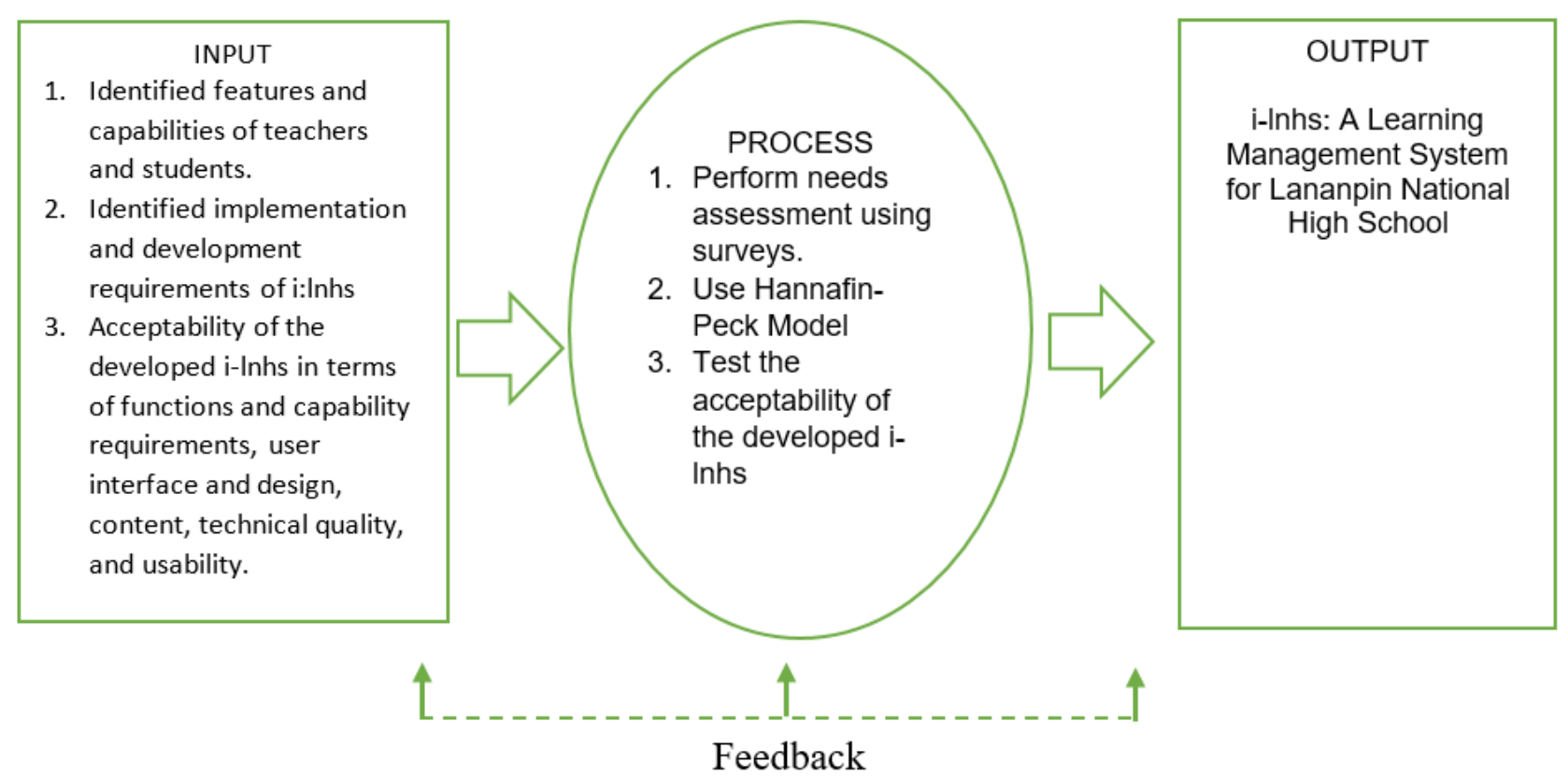

Fig 1. Project Paradigm 


\section{Methodology}

This chapter explains the techniques, designs, and procedures that the researchers used to collect data to implement-lnhs.

\subsection{Research Design}

This study used a descriptive and developmental research design. A descriptive study is a type of analysis that accurately and methodically describes the population, situation, or behavior under consideration. It focuses on providing answers to questions such as how and where ${ }^{(20)}$.

Participants in this study were interview for data gathering purposes. Collected data/information was used to evaluate the frequent issues/problems and the need for new or additional solutions to address this issues/problems.

Developmental research has been described as the systematic study of designing, creating, and evaluating instructional programs, processes, and products that must meet internal consistency and effectiveness criteria. In the field of instructional technology, developmental research is especially significant. The most popular forms of developmental research include circumstances in which the product development process was studied and represented, and the final product was evaluated ${ }^{(21)}$.

\subsection{Research Instrument}

A survey questionnaire with the use of the Likert scale was used as an instrument for this study. The data was collected through google forms. The first questionnaire was used to identify a learning management system's features and capabilities that teachers and students need to facilitate the learning process. The second questionnaire was used to assess the validity and acceptability of i-lnhs in terms of (a) Functions and Capability Requirements (b) User Interface and Design (c) Content (d)Technical quality, and (e) Usability.

A Likert scale evaluation tool was utilized to determine the features and capabilities that teachers and students want to include in the LMS and to assess the acceptability of the developed system. Respondents were asked to rate the criteria based on their degree of agreement. The researchers used a four-point Likert scale.

To check the validity of the research instrument, researchers did a pilot-testing with the teachers, IT professionals, and few students who were not included in the study's respondents to evaluate the i-lnhs and survey questionnaire.

During the pilot testing, the researchers noticed some areas that needed to improve, such as adding restrictions to features that will improve the organization and access of learning content; for example, a student can't proceed to the next activity unless the student finishes accomplishing the required tasks. Moreover, random questions in the pre-test and post-test, appealing multimedia graphics, and image content used in the LMS were modified.

\subsection{I-Inhs Development Process}

This research and development study used Hannafin-Peck Model to design and implement i-lnhs. The implementation went through the three phases of this model.

The Assessment Phase occurs during the first stage of development. During this process, the researcher conducted a needs analysis through survey questionnaires and the researcher's implementation objectives. Plan activities and projects, processes, procedures, and specifications to complete the whole design viewpoint and implementation.

During the Design Phase, the actual designing of the e-learning took place. Furthermore, online instructional resources, and materials and multimedia components, layout, storyboards, and outlines were created in this stage.

Development and Implementation is the final phase of the Hannafin-Peck Model. This phase includes developing and designing the e-learning program and the actual implementation or deployment to users ${ }^{(22)}$. Proofreading and uploading of learning content should be taken care of in this phase. Alpha testing or pilot testing were done to make sure of its functionality and usability.

To improve the quality and consistency of the e-learning experience, this instructional model includes a revision and evaluation that will follow in each of the phases mentioned above. These steps will ensure the validity and organization of the LMS to provide quality e-learning tools for the users.

The researchers could fix errors or problems in each phase separately because evaluation and revisions can be done as researchers go along the different phases. 


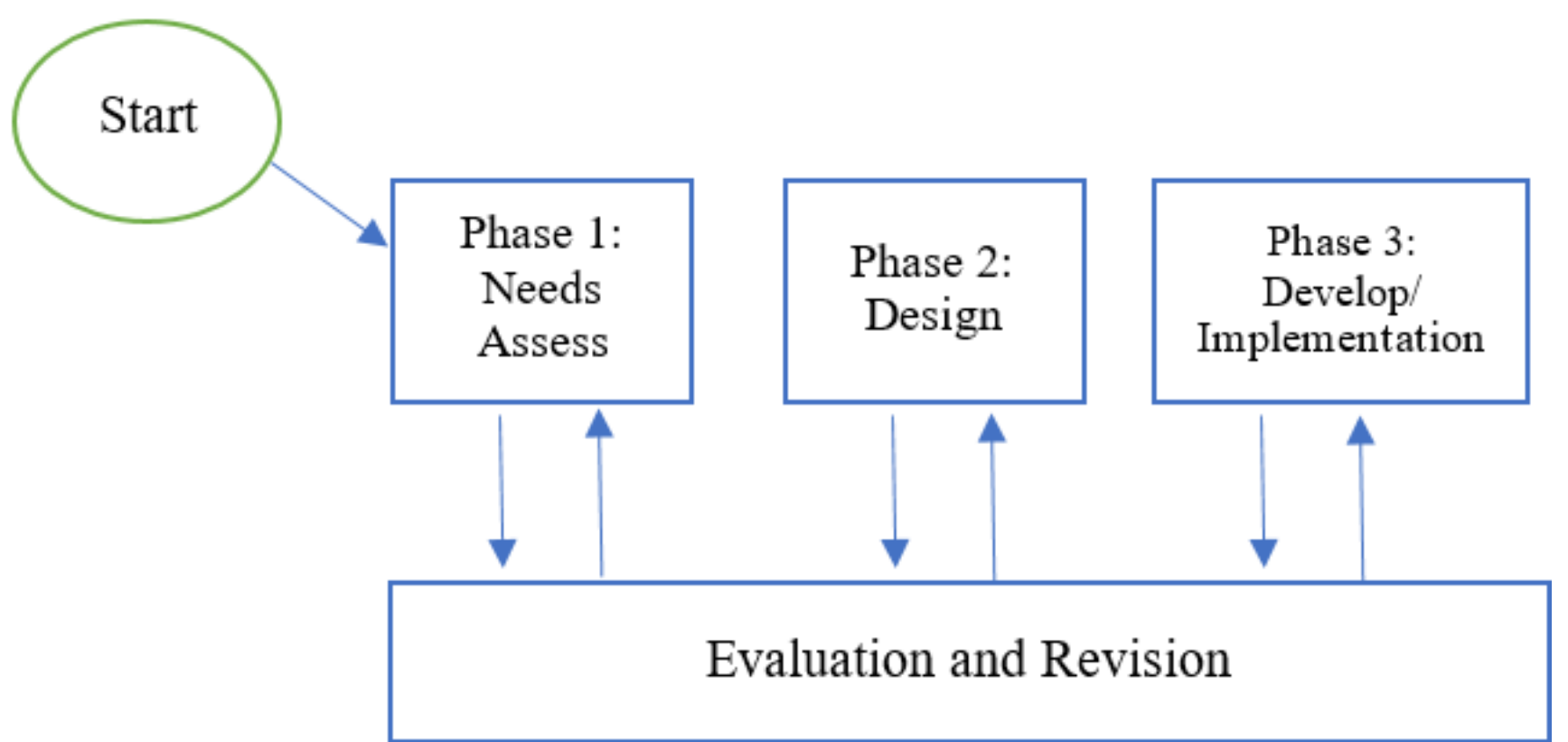

Fig 2. The i-lnhs implementation process

\subsection{Participants of the Study}

Purposive sampling, often termed as subjective sampling, is a method of non-probability sampling in which the researcher selects variables for the sample population at their discretion. The entire sampling technique in this situation is based on the researcher's judgment and comprehension of the facts. The senior high school department was purposively chosen as a pilot user in the implementation of i-lnhs. Respondents of this study are 11 senior high teachers and 40 grade 12 students who are identified to have submitted incomplete SLMs and activity sheets and currently enrolled in the school year 2020-2021. All the participants were also identified to have an internet access at home.

\subsection{Statistical Analysis}

The following statistical methods and procedures were used to analyze and interpret the collected data.

Frequency count and percentage were used to determine the list of features and capabilities of the LMS. The features and capabilities that gained the highest number of responses would be included in the design and implementation of the i-lnhs.

The average weighted mean is calculated by giving each of the individual values a different weight. The weighted mean is equal to the arithmetic mean of all the weights are equal. Rather than each data point adding similarly to the final mean, specific data points add more "weight" than others.

The average weighted mean was used to determine the level of acceptability of the i-lnhs.

The formula for weighted Mean is:

Formula:

$$
\text { Weighted Mean }=\frac{\Sigma w p}{n}
$$

Where:

$w p=$ Number of respondents per column multiplied by the assigned numerical value $\mathrm{n}=$ The number of respondents

The following scale was used, and the average weighted mean was further analyzed and interpreted.

Response ranging from 1.00 to 2.5 is interpreted as not at all likely or not acceptable. 
Table 1. LikertScale, Range and Descriptions

\begin{tabular}{llll}
\hline Weight/Scale Interpretations & Range & Descriptive Equivalent (DE) & Descriptive \\
\hline 4 & $3.26-4.00$ & Strongly Agree (SA) & Acceptable \\
3 & $2.51-3.25$ & Agree (A) & Acceptable \\
2 & $1.76-2.5$ & Disagree (D) & Not Acceptable \\
1 & $1.00-1.75$ & Strongly Disagree (SD) & Not Acceptable \\
\hline
\end{tabular}

\section{Results and Discussions}

Based on the survey questionnaire given by the researchers, the results from the respondents were presented in this chapter.

\subsection{Features and capabilities of i-Inhs}

Table 2. Summary results in identifying LMS feature requirements of teachers and students.

\begin{tabular}{|c|c|c|c|c|}
\hline \multirow{2}{*}{ CONTENT } & \multicolumn{2}{|c|}{ For Teachers } & \multicolumn{2}{|l|}{ Students } \\
\hline & $\begin{array}{l}\text { Frequent } \\
\text { Count }\end{array}$ & $\%$ & Frequent Count & $\%$ \\
\hline \multicolumn{5}{|l|}{ A. User access } \\
\hline 1. Students and teachers will have a dedicated user account & 8 & $73 \%$ & 25 & $63 \%$ \\
\hline 2. Only students who are enrolled in the specific subject can access courses & 9 & $82 \%$ & 30 & $75 \%$ \\
\hline \multicolumn{5}{|l|}{ B. Course management } \\
\hline 1. Allow teachers to create and delete courses & 5 & $45 \%$ & 12 & $30 \%$ \\
\hline 2. Allow teachers to enrol their learners in the course & 7 & $64 \%$ & 10 & $25 \%$ \\
\hline 3. Students are allowed to enrol themselves into courses & 5 & $45 \%$ & 10 & $25 \%$ \\
\hline \multicolumn{5}{|l|}{ 4. Course content can include: } \\
\hline 4.1 Files such as (.docx., slides, and pdf) & 7 & $64 \%$ & 18 & $45 \%$ \\
\hline 4.2 Videos, Audios, and Graphics & 10 & $91 \%$ & 29 & $73 \%$ \\
\hline 4.3 External links or integrate other presentations from other websites. & 6 & $55 \%$ & 18 & $45 \%$ \\
\hline 4.4 Progress of completion of courses are displayed to students & 7 & $64 \%$ & 35 & $88 \%$ \\
\hline \multicolumn{5}{|l|}{ C. Interactions } \\
\hline 1. The teachers can post announcements & 11 & $100 \%$ & 22 & $55 \%$ \\
\hline $\begin{array}{l}\text { 2. The teachers can pose questions for discussion, encourage students to ask } \\
\text { questions online, and respond online. }\end{array}$ & 10 & $91 \%$ & 29 & $73 \%$ \\
\hline $\begin{array}{l}\text { 3. Students can create discussion forums and can comment on other forum } \\
\text { topics }\end{array}$ & 7 & $64 \%$ & 13 & $33 \%$ \\
\hline \multicolumn{5}{|l|}{ D. Assignments/tasks/activities } \\
\hline 1. Teachers can create assignments and can set a due date and highest grade. & 7 & $64 \%$ & 20 & $50 \%$ \\
\hline 2. Students can view and submit assignments online & 8 & $73 \%$ & 27 & $68 \%$ \\
\hline $\begin{array}{l}\text { 3. Late tasks are acceptable, but the level of tardiness is specifically shown } \\
\text { to the instructor. }\end{array}$ & 7 & $64 \%$ & 15 & $38 \%$ \\
\hline 4. Students can view feedback from the teachers & 7 & $64 \%$ & 19 & $48 \%$ \\
\hline \multicolumn{5}{|l|}{ E. Assessments } \\
\hline 1. Teachers can design and set quizzes and tests. & 9 & $82 \%$ & 29 & $73 \%$ \\
\hline 2. Students can take assessments online & 9 & $82 \%$ & 19 & $48 \%$ \\
\hline $\begin{array}{l}\text { 3. Students can view their scores immediately and correct answers after each } \\
\text { test. }\end{array}$ & 8 & $73 \%$ & 20 & $50 \%$ \\
\hline 4. Students are allowed to take more than one attempt. & 6 & $55 \%$ & 38 & $95 \%$ \\
\hline \multicolumn{5}{|l|}{ F. Grades } \\
\hline 1. Teachers can design and set grade computations & 6 & $55 \%$ & 25 & $63 \%$ \\
\hline 2. Teacher can access grades of each student & 7 & $64 \%$ & 31 & $78 \%$ \\
\hline 3. Students can view their grades & 9 & $82 \%$ & 40 & $100 \%$ \\
\hline \multicolumn{5}{|l|}{ G. Reports } \\
\hline 1. Students can view their course and activity completion progress. & 9 & $82 \%$ & 31 & $78 \%$ \\
\hline
\end{tabular}




\begin{tabular}{|c|c|c|c|c|}
\hline Table 2 continued & & & & \\
\hline $\begin{array}{l}\text { 2. Teachers can access course and activity completion report so that } \\
\text { they can assess intervention and remediation and can provide immediate } \\
\text { feedback }\end{array}$ & 7 & $64 \%$ & 31 & $78 \%$ \\
\hline 3. Monitor students' attendance by tracking logs and access & 7 & $64 \%$ & 14 & $35 \%$ \\
\hline
\end{tabular}

Table 2 A shows that teachers are likely to have dedicated user accounts with a $73 \%$ in total. It shows that $82 \%$ of the teachers are likely to allow enrolled students in specific subjects to access their courses.

In terms of course management, it shows in Table $2 \mathrm{~B}$ teachers are likely to create and delete courses with $45 \%$ in total, and $64 \%$ of teachers likely to enroll their learners in the course. The teachers are likely to include the Files (e.g., .docx, slides and pdf), Videos, Audios and Graphics, External links in the course content with $64 \%, 91 \%$, and 55\% teachers, respectively. Students are likely to monitor their progress by displaying course completion progress with $88 \%$.

Table 2C also shows that $100 \%$ of teachers are likely to post an announcement in the system. Teachers are likely to post questions for discussion, encourage students to ask questions online, and respond online with $91 \%$. Further, table 1 shows that teachers allow students to create discussion forums and comment on other forum topics with $74 \%$.

The results are shown in Table $2 \mathrm{D}$, teachers are likely to create assignments and set due dates and highest grades with $64 \%$. $73 \%$ of the teachers are likely to allow students to view and submit assignments online. $64 \%$ of the teachers are likely to accept student's late tasks, and the level of tardiness is shown to the instructor. Further, Table 2.D shows that teachers are likely to view feedback from the teachers with $64 \%$.

Table $2 \mathrm{E}$ shows that $82 \%$ of the teachers are likely to design and set quizzes and tests. Teachers are likely to allow students to take assessments online with $82 \%$ of them. Teachers likely allow students to view their scores immediately and correct answers after each with $73 \%$. Further, students are likely to take more than one attempt of assessment with $95 \%$.

Table 2 F, 55\% of the teachers are likely to design and set grade computations and can access each student's grades with $64 \%$ of the total teacher respondent. It also shows that $82 \%$ of the teachers are likely to allow students to view their grades and students with $100 \%$.

Table $2 \mathrm{G}$ shows that teachers are likely to allow students to view their course and activity completion progress with $64 \%$. Teachers are also likely to access course and activity completion reports to access intervention and remediation and provide immediate feedback with $64 \%$. Further, teachers are likely to monitor students' attendance by tracking logs and access.

Noticeably, this indicates that features gathered with a higher percentage frequency count will be available to those users (teachers/students).

\subsection{Developing the i-Inhs}

This descriptive and developmental study used the Hannafin-Peck Model where the three phases of development were adapted. The researcher used Moodle as their platform to design and implement the i-lnhs. Moodle is an online Learning Management system enabling educators to create their private website filled with dynamic courses that extend learning anytime, anywhere. It caters to standard features that meet the learning process.

In the Assessment phase. A survey questionnaire was given to identify the features and capabilities of i-lnhs that teachers and students need to facilitate the learning process. IT experts and the researchers validated survey results. Plan activities, processes, and brainstorming were conducted to create a full view of the i-lnhs. Researchers also assessed specifications and requirements to implement i-lnhs using moodle application.

In the Design phase, after identifying features and capabilities of i-lnhs, researchers start to create storyboards, layouts, and outlines of the i-lnhs.

The researchers asked the teachers to prepare their e-learning materials and multimedia content such as modules, videos, audio and PowerPoint presentation, etc.

In the Development and Implementation Phase, researchers organized all elements identified and start customizing the moodle to meet the needs of the teachers and students. Features highlighted are the following: students and teachers logged into the i-lnhs were able to view modules, activities, take quizzes, and upload assignments. Students' progress, scores, and feedback can easily be monitored using it. Teachers can upload learning materials in different formats such as videos, images, PowerPoint, pdf, doc, and Shareable Content Object Reference Model (SCORM) from other applications. Reminders for due dates and notification were also included in the LMS to ensure students and teachers monitor activities performed and needs to perform.

Researchers conducted Alpha testing and asked 2 IT experts to validate the moodle's usability and functionality. After the evaluation, some revisions were noted and carried out by the researchers. 
Beta testing was conducted on teachers and students and ask them to evaluate the acceptability of i-lnhs by answering the survey given through google forms. Teachers were given first their access accounts to upload lessons in the LMS and able to set up other elements such as creating subjects or courses, enrolling students, posting announcements, and others to facilitate learning in their subjects. After which students were given user accounts to access courses and performed tasks given.

Since Lananpin National High School will have its first implementation of LMS, online orientation and training were conducted to teachers and students before they access the i-lnhs.

Screenshots of the i-lnhs are shown below:

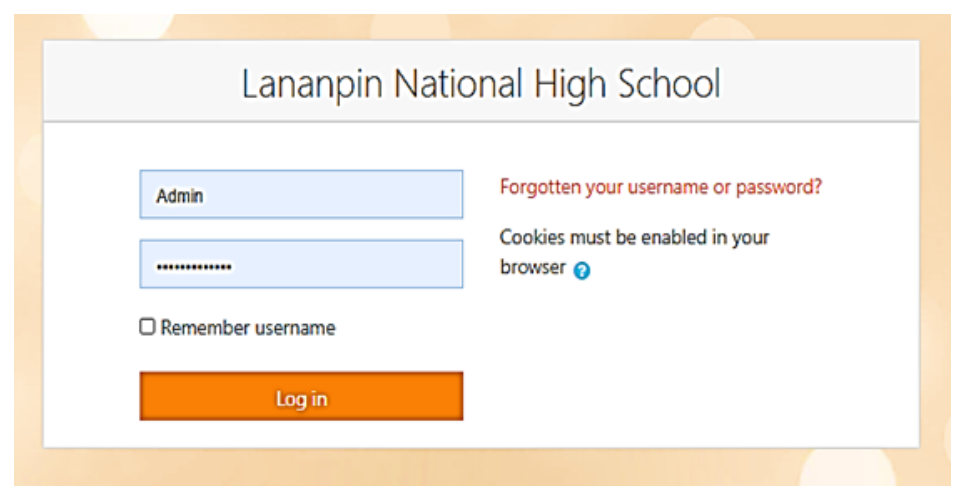

Fig 3. Login page. Teachers and students were givenaccess accounts, and the IT facilitator was given an admin account.

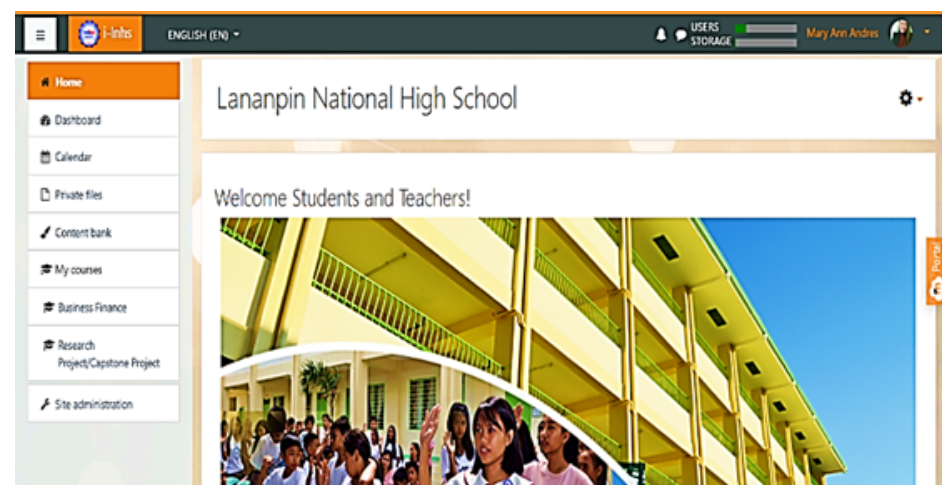

Fig 4. Home Page. On this page, access to features isbased on the user roles given.

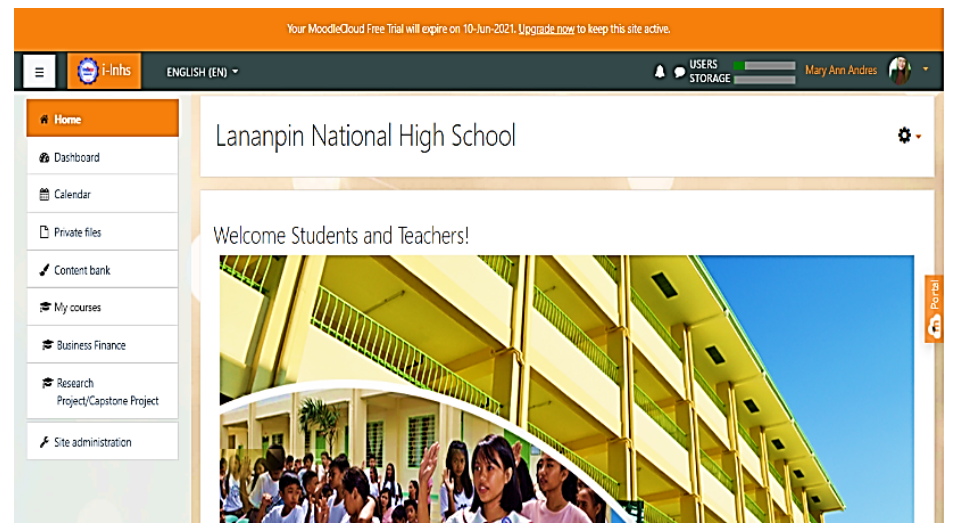

Fig 5. Home Page. On this page, access to features is based on the user roles given. 
Applied Subjects

Home / Courses / Applied Subjects

Course categories: Applied Subjects *

Search courses $Q$

- Research Project

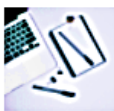

This culminating activity develops critical thinking and problem-solving skills through qualitative and quantitative researches

Add a new course

Fig 6. Adding course. This is the page where teachers can add courses in the LMS. This feature is only permitted to the teacher and admin account.

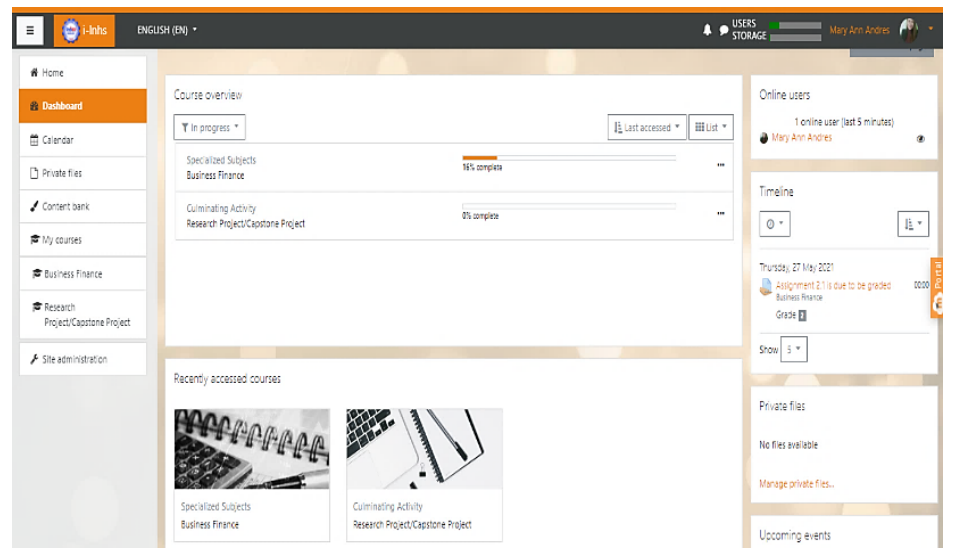

Fig 7. Dashboard. The dashboard shows course/s that available to access. It also displays course progress,events, announcement, and reminders of the deadline.

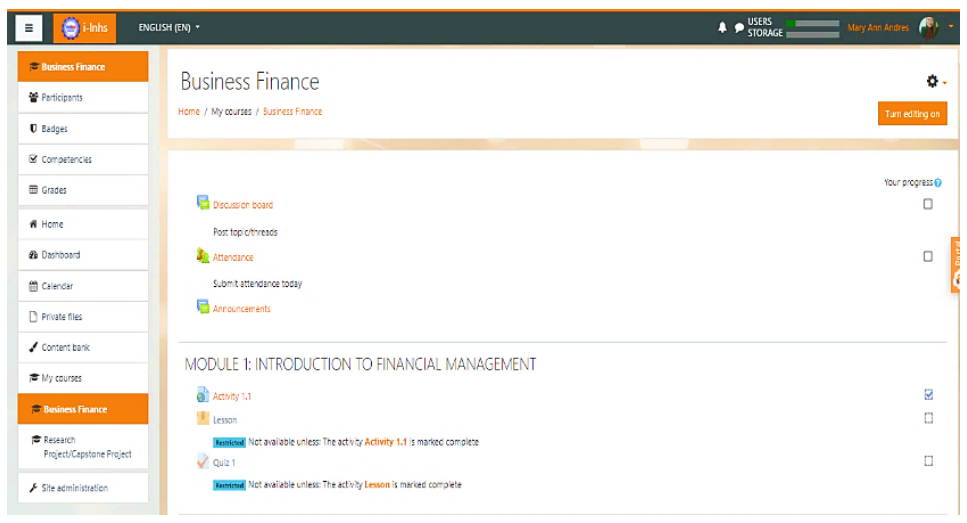

Fig 8. Course page.This page shows the course contents where students can access learning material, view, comment on a forum, attend attendance, and perform course tasks, assignments, and quizzes. 

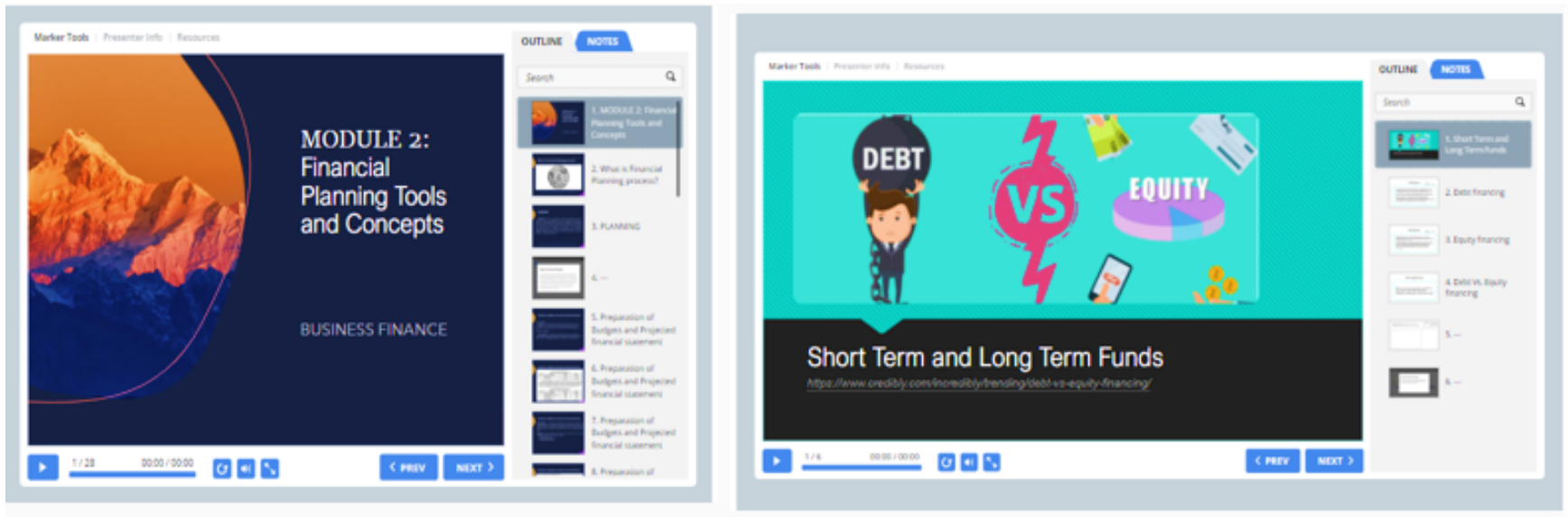

Fig 9.

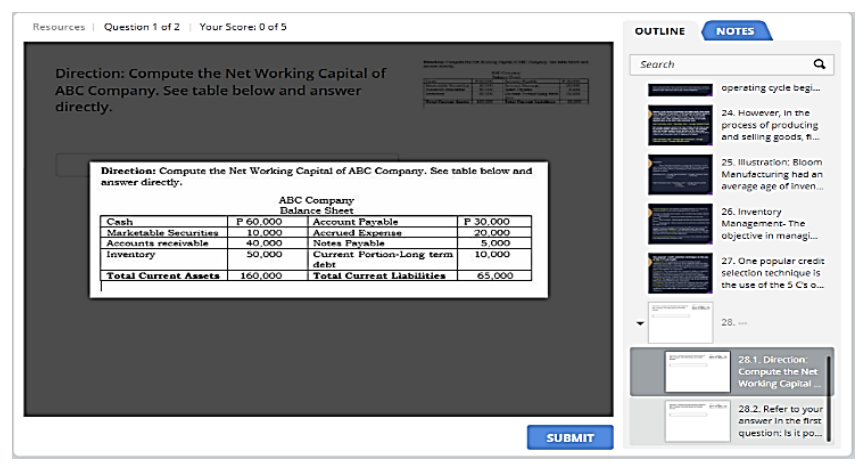

Fig 10. Module Activity.This screenshot shows an example of an activity.

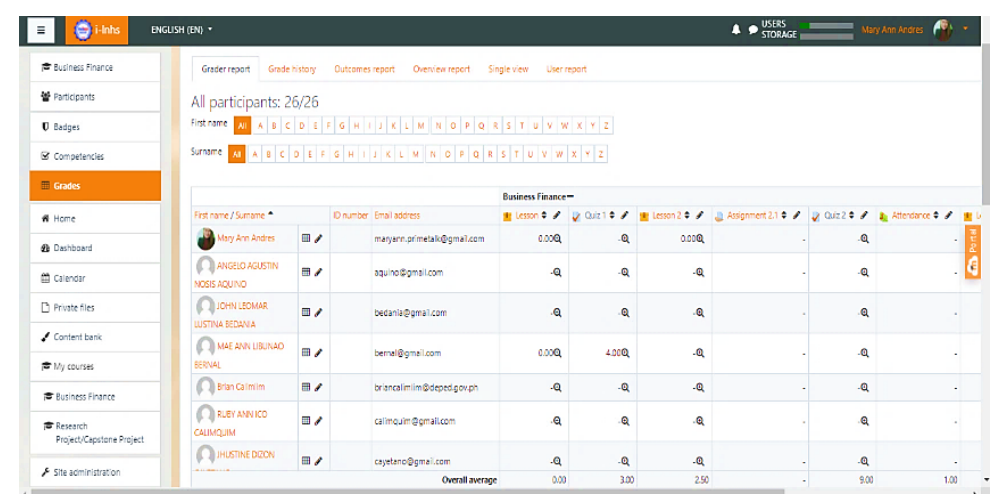

Fig 11. Grades. This page displays accomplished tasks and corresponding grades/scores for each of the tasks undertaken. This page is accessible to teachers while another page to accessed individual grades of students. 


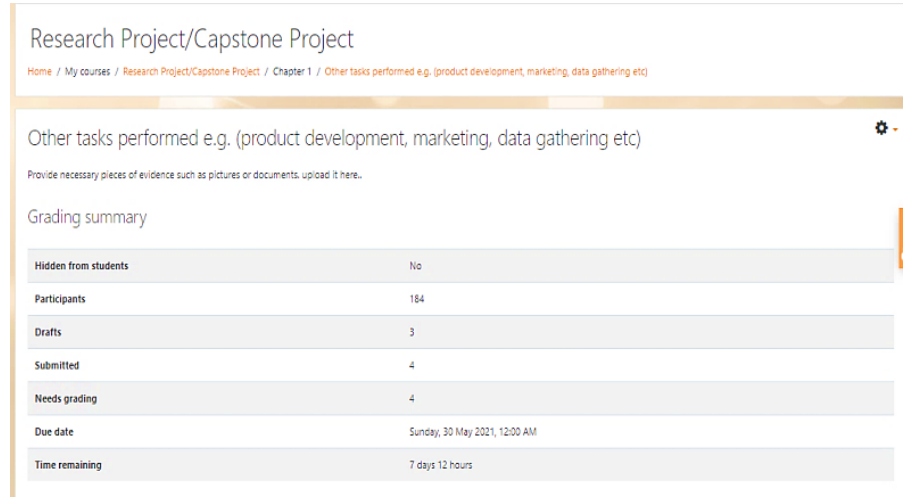

Fig 12. Activity uploads. This page displays summary submissions of tasks and assignments where teachers can easily monitor whose performing whose submitting tasksor not.

\subsection{Acceptability of i-Inhs for the Senior High School teachers and students}

Acceptability questionnaires for teachers and students distributed as assessed along with the following criteria below:

The following code was used:

$\mathrm{WE}=$ Weighted Mean $\mathrm{DE}=$ Descriptive Equivalent DI $=$ Descriptive Interpretation

Table 3. Resultsof the teachers and students' evaluation on the acceptability of i-lnhs

\begin{tabular}{|c|c|c|c|c|c|c|}
\hline \multirow{2}{*}{ CONTENT } & \multicolumn{3}{|c|}{ For Teachers } & \multicolumn{3}{|c|}{ Students } \\
\hline & WM & $\mathrm{DE}$ & DI & WM & $\mathrm{DE}$ & DI \\
\hline \multicolumn{7}{|l|}{ I. Functional requirements } \\
\hline \multicolumn{7}{|l|}{ A. User access } \\
\hline $\begin{array}{l}\text { 1. Students and teachers will have a } \\
\text { dedicated user account }\end{array}$ & 3.45 & Strongly Agree & Acceptable & 3.19 & Agree & Acceptable \\
\hline $\begin{array}{l}\text { 2. Only students who are enrolled in the } \\
\text { specific subject can access courses }\end{array}$ & 3.36 & Strongly Agree & Acceptable & 3.21 & Agree & Acceptable \\
\hline Average Weighted Mean & 3.41 & & & 3.2 & & \\
\hline \multicolumn{7}{|l|}{ B. Course management } \\
\hline $\begin{array}{l}\text { 1. Allow teachers to create and delete } \\
\text { courses }\end{array}$ & 3.36 & Strongly Agree & Acceptable & & & \\
\hline $\begin{array}{l}\text { 2. Allow teachers and admins to enroll } \\
\text { their learners in the course }\end{array}$ & 3.54 & Strongly Agree & Acceptable & 3.17 & Agree & Acceptable \\
\hline $\begin{array}{l}\text { 3. Students are allowed to enroll them- } \\
\text { selves into courses }\end{array}$ & 3.36 & Strongly Agree & Acceptable & & & \\
\hline \multicolumn{7}{|l|}{ 4. Course content can include: } \\
\hline 4.1 Files such as (docx., slides, and pdf) & 3.36 & Strongly Agree & Acceptable & 3.19 & Agree & Acceptable \\
\hline 4.2 Videos, Audios, and Graphics & 3.36 & Strongly Agree & Acceptable & 3.25 & Agree & \\
\hline 4.3 External links or integrate other & 3.19 & Agree & Acceptable & 3.19 & Agree & Acceptable \\
\hline presentations from other websites. & 3.45 & Strongly Agree & Acceptable & 3.28 & Strongly & \\
\hline $\begin{array}{l}\text { 4.4 Progress of completion of courses are } \\
\text { displayed to students }\end{array}$ & & & & & Agree & Acceptable \\
\hline & & & & & & Acceptable \\
\hline Average Weighted Mean & 3.37 & & & 3.17 & & \\
\hline \multicolumn{7}{|l|}{ C. Interactions } \\
\hline 1. The teachers can post announcements & 4.00 & Strongly Agree & Acceptable & 3.51 & $\begin{array}{l}\text { Strongly } \\
\text { Agree }\end{array}$ & Acceptable \\
\hline $\begin{array}{l}\text { 2. The teachers can pose questions for } \\
\text { discussion, encourage students to ask } \\
\text { questions online, and respond online. }\end{array}$ & 3.90 & Strongly Agree & Acceptable & 3.36 & $\begin{array}{l}\text { Strongly } \\
\text { Agree }\end{array}$ & Acceptable \\
\hline
\end{tabular}

Continued on next page 


\begin{tabular}{|c|c|c|c|c|c|c|}
\hline \multicolumn{7}{|l|}{ Table 3 continued } \\
\hline $\begin{array}{l}\text { 3. Students can create discussion forums } \\
\text { and can comment on other forum topics }\end{array}$ & 3.45 & Strongly Agree & Acceptable & 3.26 & $\begin{array}{l}\text { Strongly } \\
\text { Agree }\end{array}$ & Acceptable \\
\hline Average Weighted Mean & 3.78 & & & 3.38 & & \\
\hline \multicolumn{7}{|l|}{ D. Assignments/tasks/activities } \\
\hline $\begin{array}{l}\text { 1. Teachers can create assignments and } \\
\text { can set the due date and highest grade. }\end{array}$ & 3.90 & Strongly Agree & Acceptable & 3.14 & Agree & Acceptable \\
\hline $\begin{array}{l}\text { 2. Students can view and submit assign- } \\
\text { ments online }\end{array}$ & 3.82 & Strongly Agree & Acceptable & 3.23 & Agree & Acceptable \\
\hline $\begin{array}{l}\text { 3. Late tasks are acceptable, but the level } \\
\text { of tardiness is specifically shown to the } \\
\text { instructor. }\end{array}$ & 3.90 & Strongly Agree & Acceptable & 3.32 & $\begin{array}{l}\text { Strongly } \\
\text { Agree }\end{array}$ & Acceptable \\
\hline $\begin{array}{l}\text { 4. Students can view feedback from the } \\
\text { teachers }\end{array}$ & 3.82 & Strongly Agree & Acceptable & 3.28 & $\begin{array}{l}\text { Strongly } \\
\text { Agree }\end{array}$ & Acceptable \\
\hline Average Weighted Mean & 3.86 & & & 3.24 & & \\
\hline \multicolumn{7}{|l|}{ E. Assessments } \\
\hline $\begin{array}{l}\text { 1. Teachers can design and set quizzes } \\
\text { and tests. }\end{array}$ & 3.82 & Strongly Agree & Acceptable & 3.26 & $\begin{array}{l}\text { Strongly } \\
\text { Agree }\end{array}$ & Acceptable \\
\hline 2. Students can take assessments online & 3.82 & Strongly Agree & Acceptable & 3.19 & Agree & Acceptable \\
\hline $\begin{array}{l}\text { 3. Students can view their scores imme- } \\
\text { diately and correct answers after each } \\
\text { test. }\end{array}$ & 3.63 & Strongly Agree & Acceptable & 3.30 & $\begin{array}{l}\text { Strongly } \\
\text { Agree }\end{array}$ & Acceptable \\
\hline $\begin{array}{l}\text { 4. Students are allowed to take more than } \\
\text { one attempt. }\end{array}$ & 3.45 & Strongly Agree & Acceptable & 3.21 & Agree & Acceptable \\
\hline Average Weighted Mean & 3.68 & & & 3.23 & & \\
\hline \multicolumn{7}{|l|}{ F. Grades } \\
\hline $\begin{array}{l}\text { 1. Teachers can design and set grade } \\
\text { computations }\end{array}$ & 2.64 & Agree & Acceptable & 3.28 & $\begin{array}{l}\text { Strongly } \\
\text { Agree }\end{array}$ & Acceptable \\
\hline $\begin{array}{l}\text { 2. Teacher can access grades of each } \\
\text { student }\end{array}$ & 3.90 & Strongly Agree & Acceptable & 3.36 & $\begin{array}{l}\text { Strongly } \\
\text { Agree }\end{array}$ & Acceptable \\
\hline 3. Students can view their grades & 3.82 & Strongly Agree & Acceptable & 3.45 & $\begin{array}{l}\text { Strongly } \\
\text { Agree }\end{array}$ & Acceptable \\
\hline Average Weighted Mean & 3.45 & & & 3.36 & & \\
\hline \multicolumn{7}{|l|}{ G. Reports } \\
\hline $\begin{array}{l}\text { 1. Students can view their course and } \\
\text { activity completion progress. }\end{array}$ & 3.82 & Strongly Agree & Acceptable & 3.32 & $\begin{array}{l}\text { Strongly } \\
\text { Agree }\end{array}$ & Acceptable \\
\hline $\begin{array}{l}\text { 2. Teachers can access course and activ- } \\
\text { ity completion report so that they can } \\
\text { assess intervention and remediation and } \\
\text { can provide immediate feedback }\end{array}$ & 3.63 & Strongly Agree & Acceptable & & & \\
\hline $\begin{array}{l}\text { 3. Monitor students' attendance by } \\
\text { tracking logs and access }\end{array}$ & 3.63 & Strongly Agree & Acceptable & & & \\
\hline Average Weighted Mean & 3.69 & & & 3.32 & & \\
\hline \multicolumn{7}{|l|}{ II. User interface and design } \\
\hline $\begin{array}{l}\text { 1. Contents, objects, and text layout are } \\
\text { organized and structured }\end{array}$ & 3.45 & Strongly Agree & Acceptable & 3.19 & Agree & Acceptable \\
\hline $\begin{array}{l}\text { 2. It is easy to navigate pages and follow } \\
\text { links }\end{array}$ & 3.63 & Strongly Agree & Acceptable & 3.19 & Agree & Acceptable \\
\hline $\begin{array}{l}\text { 3. Color combination is good which } \\
\text { makes the appearance of text and objects } \\
\text { readable }\end{array}$ & 3.36 & Strongly Agree & Acceptable & 3.17 & Agree & Acceptable \\
\hline Average Weighted Mean & 3.48 & & & 3.18 & & \\
\hline \multicolumn{7}{|l|}{ III. Usability } \\
\hline 1. Convenience & 3.45 & Strongly Agree & Acceptable & 3.27 & $\begin{array}{l}\text { Strongly } \\
\text { Agree }\end{array}$ & Acceptable \\
\hline $\begin{array}{l}\text { 2. Useful to keep me updated with the } \\
\text { latest progress in the course }\end{array}$ & 3.63 & Strongly Agree & Acceptable & 3.19 & Agree & Acceptable \\
\hline
\end{tabular}




\begin{tabular}{llllll}
\hline \multicolumn{1}{c}{ Table 3 continued } & & & & \\
\hline 3. Easy access to class materials & 3.45 & Strongly Agree & Acceptable & 3.15 & Agree \\
$\begin{array}{l}\text { 4. Can be accessed through different } \\
\text { devices }\end{array}$ & 3.90 & Strongly Agree & Acceptable & 3.38 & Strongly \\
$\begin{array}{l}\text { Average Weighted Mean } \\
\text { Acceptable }\end{array}$ & & & Agree & \\
\hline
\end{tabular}

Table 3 shows how the teachers and students rate the acceptability to design and implement the LMS in terms of user access, course management, interactions, assignment/tasks/activities, assessments, grades, and reports were all acceptable. Teachers and students show results of the average weighted mean of user access with 3.41 and 3.20, course management with 3.37 and 3.17, interactions with 3.78 and 3.38, assignments/tasks/activities with 3.86 and 3.24, assessments with 3.68 and 3.23, grades with 3.45 and 3.36 and reports with 3.69 and 3.32, respectively. In terms of user interface and usability, the teachers and students found the i-lnhs good and usable with the results 3.48 and 3.18 for the user interface and 3.61 and 3.23 as its rate for usability. Among the criteria that teachers rated acceptable, the criteria under Interactions: "The teachers can post announcements" got the highest weighted mean of 4.0. This means that this feature is the most acceptable and useful for teacher to relay information to their students. Meanwhile course management criteria specifically "progress of completion of courses are displayed to students" has the lowest weighted mean of 3.19. This explains that it is acceptable, but for some teachers, implication to students is that they might feel pressured if completion of progress were displayed to them.

Students rated Interaction criteria specifically: "Teachers can post announcements" has the highest weighted mean of 3.51. This means that for students it is the most acceptable feature of the LMS; they are able to update themselves regarding teacher's announcements through this feature. On the other hand, students rated the criteria "Teachers can create assignments and can set the due date and highest grade" with the lowest weighted mean of 3.14. This means that among the features used, this is the least acceptable for students.

In summary, the overall level of acceptability of teachers is higher than the students for the reason that teachers already had prior knowledge of LMS as a result of training and webinars attended compared to students whose first time to use such platform. Markedly, features available to each user were usable and acceptable in general.

\subsection{Validity i-Inhs}

Usability questionnaires were distributed to experts to assess the validity of i-lnhs along with the following criteria below:

Table 4. Results of expert's validity of the i-lnhs

\begin{tabular}{|c|c|c|c|}
\hline \multirow{2}{*}{$\begin{array}{l}\text { Criteria } \\
\text { I. Content Validity }\end{array}$} & \multicolumn{3}{|c|}{ Experts } \\
\hline & WM & $\mathrm{DE}$ & DI \\
\hline 1. Learning Materials were appropriate to achieve learning objectives & 3.5 & Strongly Agree & Acceptable \\
\hline 2. Correctness and completeness of lessons & 3.5 & Strongly Agree & Acceptable \\
\hline 3. Assessments were structured accordingly (differentiated assessments) & 3.5 & Strongly Agree & Acceptable \\
\hline 4. Resources are accessible & 4.0 & Strongly Agree & Acceptable \\
\hline 5. Lessons are well-presented & 3.5 & Strongly Agree & Acceptable \\
\hline \multicolumn{4}{|l|}{ II. Technical Quality } \\
\hline 1. Contents, objects, and text layout are organized and structured & 3.5 & Strongly Agree & Acceptable \\
\hline 2. It is easy to navigate pages and follow links & 3.0 & Strongly Agree & Acceptable \\
\hline 3. Color combination is good which makes the appearance of text and objects readable & 4.0 & Strongly Agree & Acceptable \\
\hline \multicolumn{4}{|l|}{ III. Usability } \\
\hline 1. Can be accessed through different devices & 3.5 & Strongly Agree & Acceptable \\
\hline 2. Useful to keep teachers and learners updated with the latest progress in the course & 4.0 & Strongly Agree & Acceptable \\
\hline 3. Information is available and can access anytime & 4.0 & Strongly Agree & Acceptable \\
\hline 4. Motivate students to meet subject requirements & 3.5 & Strongly Agree & Acceptable \\
\hline
\end{tabular}

Table 4 shows how the experts validated the i-lnhs regarding content validity, technical quality, and usability. Findings show that content validity average weighted mean is 3.6 , technical quality is 3.5 , usability average is 3.75 , which means the respective criteria are acceptable.

In terms of content validity, it shows that accessibility of resources got the highest weighted mean of 4.0. In terms of technical quality, the color combination and appearance both got 4.0 and in terms of usability, the feature to update progress and 
information availability has 4.0 weighted mean. These are the features that experts rated with the highest level of acceptability. Meanwhile the criteria under the technical quality, specifically the ease to navigate pages and follow links has the lowest level of acceptability with a weighted mean of 3.0. It depicts that it is not that easy to move around within the LMS. Navigation label and organization of links must be improved to help the users track the information or pages they want to access easily.

\section{Conclusion}

The findings show from the thorough analysis, development, and evaluation of the study drawn the following conclusions. The needs analysis regarding features and capabilities of LMS showed what features were available to teachers and to students and highly recommended implementing the i-lnhs. With the identified features and capabilities of LMS, moodle was designed and implemented using the Hannafin-Peck Model.

Finally, the evaluation from the experts, students, and teachers showed a positive result and is acceptable in terms of i-lnhs content validity, functional requirements, technical quality, and usability. Though there were gaps in teachers' and students' rates in their evaluation showing teachers have a higher rate of acceptability than students.

With the use of the i-lnhs, teachers and students who have access to the internet and gadgets or computers got the chance to experience the use of e-learning tools, and this research shown how implemented LMS can be useful to teachers and students to facilitate online learning. Future implementation of Moodle as LMS, could accommodate described settings or enhanced by discovering more Moodle features to foster more interaction and a flexible e-learning environment.

\section{Recommendations}

With the positive results from the study, researchers highly recommend the following: The designed and implemented Moodle, which is the i-lnhs should be tested and implemented to a large group of users to determine its efficiency to handle the larger volume of users and should be evaluated for further updates and upgrades. In addition, conduct further training for students and teachers on how to utilize and use the LMS potentials.

Continuing program development is also recommended in relevant research since it has been adequate for education development. The researchers recommend that the performed study be implemented in the Division schools to innovate their pupils' learning experiences. Further research is required to improve the current system or incorporate innovative features and new trends material into the i-lnhs that would benefit the school.

\section{References}

1) Donghyun K. The impact of learning management systems on academic performance: Virtual Competency and Student Involvement. Journal of Higher Education Theory and Practice. 2017;17(2). Available from: http://www.nabusinesspress.com/JHETP/KimD_Web17_2_.pdf.

2) The World Bank World Bank Education and COVID-19. 2021. Available from: https://www.worldbank.org/en/data/interactive/2020/03/24/world-bankeducation-and-covid- 19.

3) UNESCO COVID-19 Educational Disruption and Response. 2021. Available from: https://en.unesco.org/covid19/educationresponse\# schoolclosureseducationresponse.

4) Osman ME. Global impact of COVID-19 on education systems: the emergency remote teaching at Sultan Qaboos University. Journal of Education for Teaching. 2020;46(4):463-471. Available from: https://dx.doi.org/10.1080/02607476.2020.1802583.

5) Llego M. DepEd Learning Management System (LMS) and Electronic Self-Learning Modules (e-SLMs). 2021. Available from: https://www.teacherph. com/deped-learning-management-system-lms-electronic-self-learning-modules.

6) Malipot M, Hernando M. Parents prefer modular learning for their children this school year, DepEd survey finds out. Manila Bulletin.

7) Guragain N. E-learning benefits, and applications. Helsinki Metropolia University of Applied Sciences. 2016.

8) Clemen I, Ali H, Abdulmadid A, Jabbar J. Education During COVID-19 Era: Readiness of Students in a Less-Economically Developed Country for E-Learning. Helsinki Metropolia University of Applied Sciences. 2021;1(2).

9) Fayomi O, Ayo CK, Ajayi L, Okorie U. The Impacts Of E-Learning in Facilitating Academic Performance Among Private Secondary Schools saA Tertiary Institutions In Ota. IMCC Journal of Science. 2015. Available from: http://eprints.covenantuniversity.edu.ng/9402/\#.YNF88mgzbIU.

10) Ahmed K, Mesonovich M. Learning Management Systems and Student Performance. International Journal for e-Learning Security. $2019 ; 8(1): 582-591$. Available from: https://dx.doi.org/10.20533/ijels.2046.4568.2019.0073.

11) Hurix. Understanding the Relevance of Learning Management Systems in Education. 2021. Available from: https://www.hurix.com/learningmanagement-systems-in-education/.

12) Yusuf I, Widyaningsih SW, Prasetyo ZK, Istiyono E. Development of Moodle Learning Management System-Based E-Learning Media in Physics Learning. Proceedings of the Tarumanagara International Conference on the Applications of Social Sciences and Humanities (TICASH 2019). 2020. Available from: https://doi.org/10.2991/assehr.k.200515.042.

13) Reischl V, Toro JTM. Learning Management Systems. 2021. Available from: https://edd7032017f2.pressbooks.com/chapter/2/.

14) What is moodle?. 2021. Available from: https://ethinkeducation.com/what-is-moodle-guide/\#MoodleforEducation.

15) Campo M, Amandi A, Biset JC. A software architecture perspective about Moodle flexibility for supporting empirical research of teaching theories. Education and Information Technologies. 2021;26(1):817-842. Available from: https://dx.doi.org/10.1007/s10639-020-10291-4. 
16) Chourishi D, Buttan CK, Chaurasia A, Soni A. Effective E-Learning through Moodle. International Journal of Advance Technology \& Engineering Research. 2011;1(1):34-38.

17) Alhothli N. Investigating the Impact of Using Moodle as an E-Learning Tool for Students in an English Language Institute" Graduate Student Theses, Dissertations, \& Professional Papers. Graduate Student Theses. 2015. Available from: https://scholarworks.umt.edu/etd/4524.

18) Gutierrez K. A Quick Guide to Four Instructional Design Models. 2020. Available from: https://www.shiftelearning.com/blog/top-instructional-designmodels-explained.

19) Pappas C. Applying the Hannafin-Peck Model In eLearning. 2021. Available from: https://www.efrontlearning.com/blog/2016/03/applying-thehannafin-peck-model-in-elearning.html\#: .

20) Mccombes S. Descriptive research. 2021. Available from: https://www.scribbr.com/methodology/descriptive-research/.

21) Richey R. Developmental Research. "Investigating the Impact of Using Moodle as an E-Learning Tool for Students in an English Language Institute. 2009. Available from: https://scholarworks.umt.edu/etd/4524.

22) Aguilar M, Coloma R, Mariñas D, Patacsil F. Development and Validity of Computer Aided Instruction for the least learned topics in Animation NC II. International Journal of Advanced Trends in Computer Science and Engineering. 2021;10(1):82-91. 